\title{
Complete Resistance by Carnation Cultivars to Fusarium Wilt Induced by Fusarium oxysporum f. sp. dianthi Race 2
}

\author{
Y. Ben-Yephet, M. Reuven, and D. Shtienberg, Department of Plant Pathology, ARO, The Volcani Center, P.O. \\ Box 6, Bet Dagan 50250, Israel
}

\begin{abstract}
Ben-Yephet, Y., Reuven, M., and Shtienberg, D. 1997. Complete resistance by carnation cultivars to Fusarium wilt induced by Fusarium oxysporum f. sp. dianthi race 2. Plant Dis. 81:777780 .

The response of two carnation (Dianthus caryophyllus) cultivars, Arbel and Scarlette, to Fusarium wilt induced by Fusarium oxysporum f. sp. dianthi race 2 was determined in experiments conducted in an infested field and using artificially inoculated plants grown in a nethouse. In six field experiments conducted from 1989-90 to 1995-96, and including more than 200 different cultivars, Arbel and Scarlette were the only ones that remained symptomless. The responses of the other cultivars varied markedly, but even those known to be highly resistant, Eveline and Novada, were frequently diseased. In the net-house tests, Arbel and Scarlette were compared with cultivars that ranged in their response to Fusarium wilt from highly resistant to highly susceptible. Due to the conducive conditions for Fusarium wilt prevailing in these tests, disease progressed rapidly, and by the end of the experiments all cultivars except Arbel and Scarlette were severely diseased (incidence of 81.2 to 100\%); Arbel and Scarlette remained symptomless. The pathogen did colonize the basal stem parts of all cultivars, including Arbel and Scarlette. The number of colony-forming units (CFU) recovered from the basal stem parts was $10^{5} \mathrm{CFU} / \mathrm{g}$ of stem in the other cultivars, $10^{3} \mathrm{CFU} / \mathrm{g}$ in Scarlette, and $50 \mathrm{CFU} / \mathrm{g}$ in Arbel. Results of our study suggest that Arbel and Scarlette exhibit a novel type of resistance to Fusarium wilt induced by F. oxysporum f. sp. dianthi race 2.
\end{abstract}

Severe epidemics of Fusarium wilt, induced by Fusarium oxysporum f. sp. dianthi (Prill. \& Delacr.) W.C. Snyder \& H.N. Hans. in carnation (Dianthus caryophyllus L.), and the desire to reduce the chemicals required for its control prompted a search for alternative means of disease management. One of the possibilities is to use cultivars resistant to the pathogen. There are three characteristics of resistance: the magnitude of the effect (high versus low), the genetic basis (governed by a single or multiple genes), and its differential nature (effective against one or more of the pathogen races) (19). Cultivars with specific (qualitative, complete) resistance generally show complete resistance to a specific race of the pathogen under most environmental conditions. On the other hand, cultivars with general (quantitative, partial) resistance are less stable and may vary in their reactions to the pathogen under different environmental conditions $(1,26)$. There may be differences between resistance to infection by the pathogen and resistance to the disease it subsequently causes. Thus, it is possible that a pathogen

Corresponding author: Y. Ben-Yephet Fax: 972-3-9683543

Accepted for publication 29 March 1997.

Publication no. D-1997-0520-05R

(C) 1997 The American Phytopathological Society will invade and reproduce (at low levels) in plants that are completely symptomless (27).

Eight races of $F$. oxysporum f. sp. dianthi are currently known, but race 2 of the pathogen is the most prevalent worldwide $(2,10,20,23)$. A number of studies have shown that the type of resistance to race 2 is partial $(4,7,15,25,29)$. Accordingly, the response of carnation cultivars to Fusarium wilt ranges from highly resistant to highly susceptible. Host response to the pathogen is determined by planting tested cultivars in an infested field or via artificial inoculation with spore suspensions. Expression of the disease, its final severity, frequency of colonization, and the number of CFU produced in the vascular system are all used as criteria for classification $(6,11,14,21,28)$. Although this procedure is adequate for pathosystems with complete resistance $(3,9,16,22)$, it may be inappropriate for pathosystems with partial resistance. In such cases, the response of cultivars may be governed by the conditions of the test. Thus, it is possible that a cultivar that shows no disease symptoms under certain conditions, and thus is classified as highly resistant, would be severely diseased under different conditions (11,13,14,21). Consequently, cultivar classification should involve comprehensive examination under diverse conditions, including those highly conducive to the pathogen.

Since 1989, routine screening tests of carnation cultivars were conducted to de- fine their responses to Fusarium wilt. The tests were carried out in a field that had been artificially infested with $F$. oxysporum f. sp. dianthi race 2. Because of repeated planting of carnation in the same field, a high population of the pathogen developed, resulting in severe disease in susceptible cultivars and mild disease in highly resistant cultivars. The response of new cultivars was compared with that of cultivars with known levels of resistance to the pathogen (14). In the course of these tests, it was noticed that two cultivars, Scarlette (introduced in 1991) and Arbel (introduced in 1992), remained symptomless until the end of the growing season. It was hypothesized that Arbel and Scarlette exhibited a new type of resistance to Fusarium wilt that allowed them to remain symptomless even under conditions favorable to the pathogen. Such resistance, if proven, may make soil fumigation prior to planting of carnations unnecessary. In the current study, the pathogenicity of $F$. oxysporum $\mathrm{f}$. sp. dianthi race 2 to Arbel and Scarlette and the resultant wilt incidence were investigated under diverse conditions.

\section{MATERIALS AND METHODS}

Field tests. A 0.1-ha field with sandy soil, naturally infested with $F$. oxysporum f. sp. dianthi race 2 , had been used annually since 1989 to study the responses of commercial and new carnation cultivars supplied by breeders in Israel and Europe. The soil was infested in 1988 by incorporating diseased carnation plants (dried and ground to powder) into the soil (14). In subsequent growing seasons, the soil at the experimental site was not subjected to further infestation because analysis of the soil each season before planting revealed a high level of inoculum. During the 1989-90 to 1995-96 growing seasons, the number of F. oxysporum f. sp. dianthi $\mathrm{CFU}$ ranged from $5 \times 10^{3}$ to $10^{4} \mathrm{CFU} / \mathrm{g}$ of soil before planting. The number of $F$. oxysporum $\mathrm{f}$. sp. dianthi propagules was counted in the soil samples as described previously (8). Briefly, air-dried soil ( $5 \mathrm{~g})$ was diluted in sterile dilute water-agar $(0.1 \%)$, and $1 \mathrm{ml}$ of this suspension was pipetted onto each of five plates with selective medium containing pentachloronitrobenzene-agar medium (24). One hundred Fusarium colonies were transferred onto potato dextrose agar supplemented with dihydrostreptomycin at $250 \mathrm{mg} / \mathrm{liter}$ (PDAS) for identification of F. oxysporum. For identification of $F$. ox- 
ysporum f. sp. dianthi, 30 colonies of $F$. oxysporum were tested for pathogenicity on the susceptible cultivar Hermon.

The infested field was divided into eight replicate blocks, each containing 40 to 65 experimental plots; the number of plots varied among years according to the number of cultivars included in the test. Each plot consisted of a bed $1 \mathrm{~m}$ wide and $1 \mathrm{~m}$ long with 32 rooted stem cuttings planted in four rows. Reference cultivars were planted in each season: Hermon (highly susceptible); Galit (moderately resistant); and Eveline (highly resistant). In 1995-96, Novada, which is classified in Europe as highly resistant to $F$. oxysporum $\mathrm{f}$. sp. dianthi (6), was included in two experiments. Disease incidence (i.e., the proportion of plants exhibiting wilt symptoms) for cultivars was evaluated approximately 180 days after planting. Disease progress leveled off at that time, and no further increase in disease occurred at later stages of the season (14). Disease incidence and not disease severity (i.e., the intensity of wilt symptoms) was the parameter used for disease assessments, because these two measures of disease are closely correlated, and because disease incidence is a more accurate, reliable, and easy-to-determine parameter than disease severity (14).

Prior to planting in the field or in the artificial inoculation tests, 20 stem segments from each of the cultivars to be tested were examined for possible contamination with $F$. oxysporum f. sp. dianthi. Stem segments (5 to $10 \mathrm{~mm}$ in length) were sampled from the basal part of the cutting, surface-sterilized, rinsed twice in sterile deionized water, and planted on the selective medium (24). Colonies of fungi that emerged from stem segments were transferred onto PDAS, and cultures resembling $F$. oxysporum were evaluated for pathogenicity by inoculating

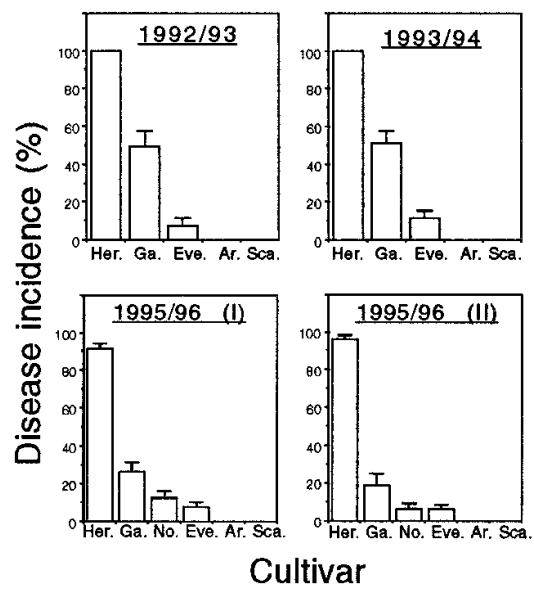

Fig. 1. Incidence of Fusarium wilt induced by Fusarium oxysporum f. sp. dianthi race 2 in five carnation cultivars planted in an infested field in Israel from 1992-93 to 1995-96. Disease incidence was assessed 180 days after planting. Bars indicate the SE. Cultivars: Her. = Hermon, Ga. $=$ Galit, No. = Novada, Eve. $=$ Eveline, Ar. $=$ Arbel, and Sca. $=$ Scarlette. the cultivar Hermon. None of the tested cuttings was infected prior to planting.

The presence of $F$. oxysporum f. sp. dianthi in the basal stem part of plants grown in the field was evaluated by isolation approximately 180 days after planting in two growing seasons. In 1993-94, this test was conducted on the cultivars Hermon, Galit, Eveline, Arbel, and Scarlette; in 1995-96, Novada was included along with the cultivars evaluated the first year. Stem segments (5 to $10 \mathrm{~mm}$ in length) were sampled from four plants in each experimental plot. Segments were peeled down to the cambium, and then the test was continued as described.

Artificial inoculation tests. Artificial inoculation tests were performed in order to examine the response of Arbel and Scarlette under conditions that are highly conducive to the pathogen. In addition to disease evaluation, colonization and recovery of $F$. oxysporum f. sp. dianthi within the plant tissue were determined. The experiments included the reference cultivars and also Novada. Two successive experiments were conducted in each of 2 years, 1994 and 1995 (four experiments in total). The first experiment in each year was initiated in the middle of June and the second at the beginning of July. Four isolates of $F$. oxysporum f. sp. dianthi race $2(10,23)$ were plated on PDAS. Equal quantities of spores from each isolate were mixed in an aqueous suspension to a final concentration of $10^{6}$ spores per ml. For each cultivar, 16 rooted cuttings were immersed in $300 \mathrm{ml}$ of the suspension for $20 \mathrm{~s}$ and then planted, four per pot, in four 3-liter pots filled with a mixture of steamed tuff (crushed volcanic stones) and peat (1:1 vol/vol). Equal quantities of the remaining spore suspension were poured onto the surfaces of the substrates. This procedure was repeated seven times to a total of 28 pots per cultivar. To ensure successful inoculation, the plants were not watered on the first day and were carefully watered, avoiding runoff, on the following 5 days. After inoculation, the plants were placed in a net-house with a screen transmitting $15 \%$ solar radiation intensity, conditions highly conducive to wilt development $(12,13)$. The experiments were laid out in a completely randomized design, with four replicates (pots) per treatment. Disease incidence was recorded every 12 to 16 days on the plants that remained until the end of the experiments, starting soon after the observation of first symptoms and continuing up to 64 days after inoculation.

The presence of $F$. oxysporum f. sp. dianthi and the number of CFU in the plant stems were determined at different times after inoculation. Stem segments $(20 \mathrm{~mm}$ in length) were sampled from three parts of the stem: basal ( 0 to $2 \mathrm{~cm}$ above ground level), middle (5 to $7 \mathrm{~cm}$ above ground level), and upper (10 to $12 \mathrm{~cm}$ above ground level). Samples included four repli- cates (pots containing four plants each) for each cultivar and were taken seven times, $1,2,4,8,16,32$, and 64 days after planting. Stem segments, each $20 \mathrm{~mm}$, were surface-sterilized as described. Then $5 \mathrm{~mm}$ of each segment was plated on PDAS to determine the presence of the fungus; the other part of the segment $(15 \mathrm{~mm}$ in length) was inserted into a plastic bag together with the corresponding parts of the three other stems in the replicate. Sterile distilled water weighing twice as much as the segments was added to each plastic bag. The segments of each sample were crushed by means of a mortar and pestle and then blended for $10 \mathrm{~min}$ in a Stomacher Lab-Blender (Seward, UK). From each sample, three $0.1-\mathrm{ml}$ aliquots of the original suspension or of a 10-fold dilution of it (according to the expected number of propagules) were pipetted onto three plates of selective medium (24). Fusarium colonies that developed after 5 days of incubation at $25^{\circ} \mathrm{C}$ were counted and processed for pathogenicity tests as described above.

Data analysis. Data were analyzed statistically using the MINITAB software (Minitab Inc.). A one-tailed $F$ test (at $P=$ 0.05 ) was used to test the null hypothesis that for each cultivar, disease incidence in the field did not differ from $0 \%$. A cultivar was regarded as completely resistant if the null hypothesis was proved. Analysis of variance was employed for comparing disease incidence at different times after inoculation in the artificial inoculation tests. Whenever the $F$ values were significant (at $P \leq 0.05$ ), a least significant difference (LSD) test was used to identify differences among cultivars. Differences among cultivars with respect to colonization frequencies and the number of $F$. oxysporum f. sp. dianthi CFU in stems were determined similarly. The number of $F$. oxysporum f. sp. dianthi CFU/g of stem $(n)$ was transformed to $\log (n$ +1 ) before analysis.

\section{RESULTS}

Field tests. The response of over 200 carnation cultivars to $F$. oxysporum $\mathrm{f}$. sp. dianthi was evaluated in field tests during 1989-90 to 1995-96. Only Scarlette (introduced in 1991-92) and Arbel (introduced in 1992-93) were symptomless. Disease incidence for the reference cultivars in four experiments over three growing seasons illustrates the variability in cultivar response to $F$. oxysporum $\mathrm{f}$. sp. dianthi (Fig. 1). For each cultivar, disease incidence varied slightly among the years, but larger differences were observed among the cultivars than among years. Disease incidences for Hermon (91.6 to $100 \%$ ), Galit (18.7 to $50.0 \%)$, Novada (6.2 to $12.5 \%$ ), and Eveline (6.2 to $11.5 \%$ ) were significantly different from $0 \%(P=0.05)$, but those of Arbel and Scarlette $(0 \%$ incidence) were not, suggesting a complete resistant reaction in the field tests. 
The incidence of colonization was related to disease assessment. In 1993-94, the fungus had colonized 100, 56, and 24\%, and in 1995-96 (experiment 1), 100, 52 , and $28 \%$ of stem segments of Hermon, Galit, and Eveline, respectively. In 199596, Novada was included in the test, and $34 \%$ of its stem segments were colonized. Although Arbel and Scarlette remained symptomless, the pathogen was reisolated from the basal stem parts of these cultivars at frequencies of 12 to $15 \%$.

Artificial inoculation tests. To determine whether Arbel and Scarlette would retain their response to Fusarium wilt under conditions highly conducive to disease development, cultivars were included in artificial inoculation tests. Results of the experiment conducted in July 1995 were similar to results for the other three experiments. Therefore, only results of the 1995 experiment are presented (Fig. 2). All plants of Hermon were diseased within 22 days after planting. By the end of the experiment (64 days after planting), disease incidences for Eveline (100\%), Galit $(93.7 \%)$, and Novada $(81.2 \%)$ also were high. However, all plants of Arbel and Scarlette remained symptomless until the end of the experiment. Moreover, some of the plants were kept in the net-house for another 150 days (until 214 days after planting), and they still remained symptomless.

The fungus had colonized and was recovered from the basal parts of the stems of all cultivars at frequencies ranging from 73 to $100 \%$ for the duration of the experiment. By the end of the experiment (64 days after planting), almost all stem segments were colonized (Fig. 3A). The number of $F$. oxysporum f. sp. dianthi $\mathrm{CFU}$ recovered for these parts increased markedly up to 16 to 32 days after inoculation but remained more or less stable thereafter. Colony numbers were relatively high $\left(10^{5}\right.$ F. oxysporum f. sp. dianthi CFU/g of stem) for Hermon, Eveline, Galit, and Novada. The pathogen was recovered also from the basal stem parts of Scarlette $\left(10^{3} F\right.$. oxysporum f. sp. dianthi CFU/g of stem) and Arbel (50 F. oxysporum f. sp. dianthi CFU/g of stem) (Fig. 3B). For the middle

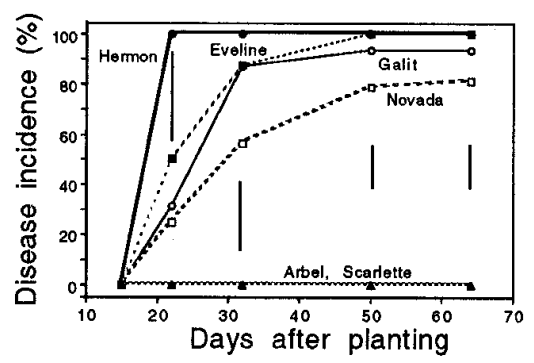

Fig. 2. Fusarium wilt progress curves for five carnation cultivars artificially inoculated with Fusarium oxysporum f. sp. dianthi race 2 and planted in a net-house in July 1995. Vertical lines represent the LSD (at $P \leq 0.05$ ) for each sampling date. and upper stem parts, colonization increased with time (data not shown) and was higher in the middle stem parts than in the upper stem parts. By the end of the experiment (64 days after planting), the pathogen had colonized and was recovered at significantly higher frequencies and numbers of CFU in cultivars Hermon, Eveline, Galit, and Novada than in Arbel and Scarlette; for the latter two cultivars, colonization ( $<15 \%$ of the stem segments) and recovery ( $<5 F$. oxysporum f. sp. dianthi CFU/g of stem) were relatively low (Fig. 3C to F).

\section{DISCUSSION}

The carnation cultivars Arbel and Scarlette remained symptomless to Fusarium wilt induced by $F$. oxysporum f. sp. dianthi race 2 under diverse conditions. These cultivars differed from all 200 other cultivars tested in the field over the years, including those that are known to be highly resistant to the disease, such as Eveline (14) and Novada (6). In carnation cultivars with partial resistance to $F$. oxysporum $\mathrm{f}$. sp. dianthi, the severity of wilt is governed to a great extent by biotic and abiotic parameters. Thus, classification of cultivar response to the pathogen may be affected by the conditions of the tests. As an example, Harling et al. (21) reported that artificial inoculation of cultivar Carrier 929 did not lead to expression of disease symptoms at $22^{\circ} \mathrm{C}$ but it did at $26^{\circ} \mathrm{C}$. In this study, Novada and Eveline exhibited low disease incidence in the field but were severely diseased in the artificial inoculation tests. On the other hand, the response of plant materials with complete resistance to vas-
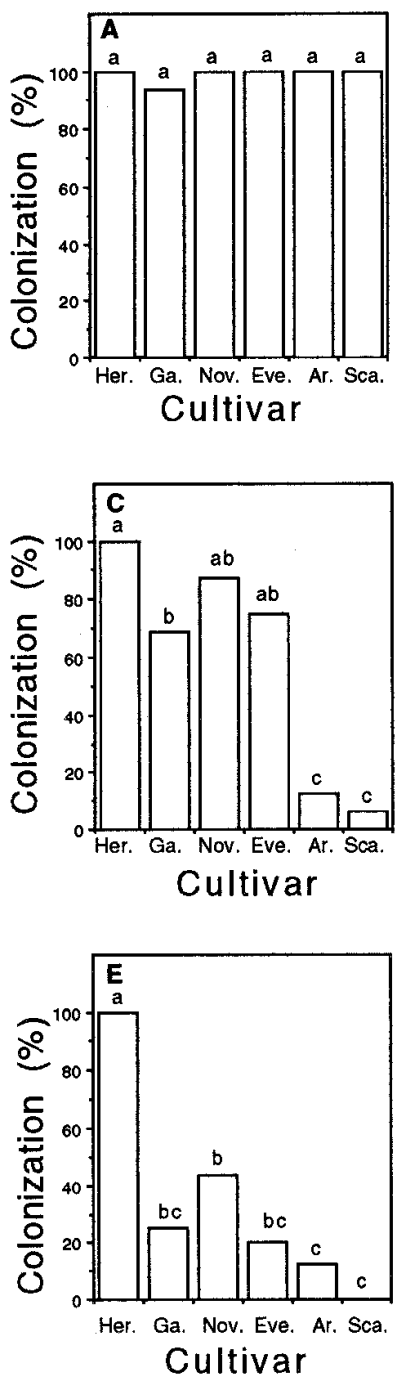
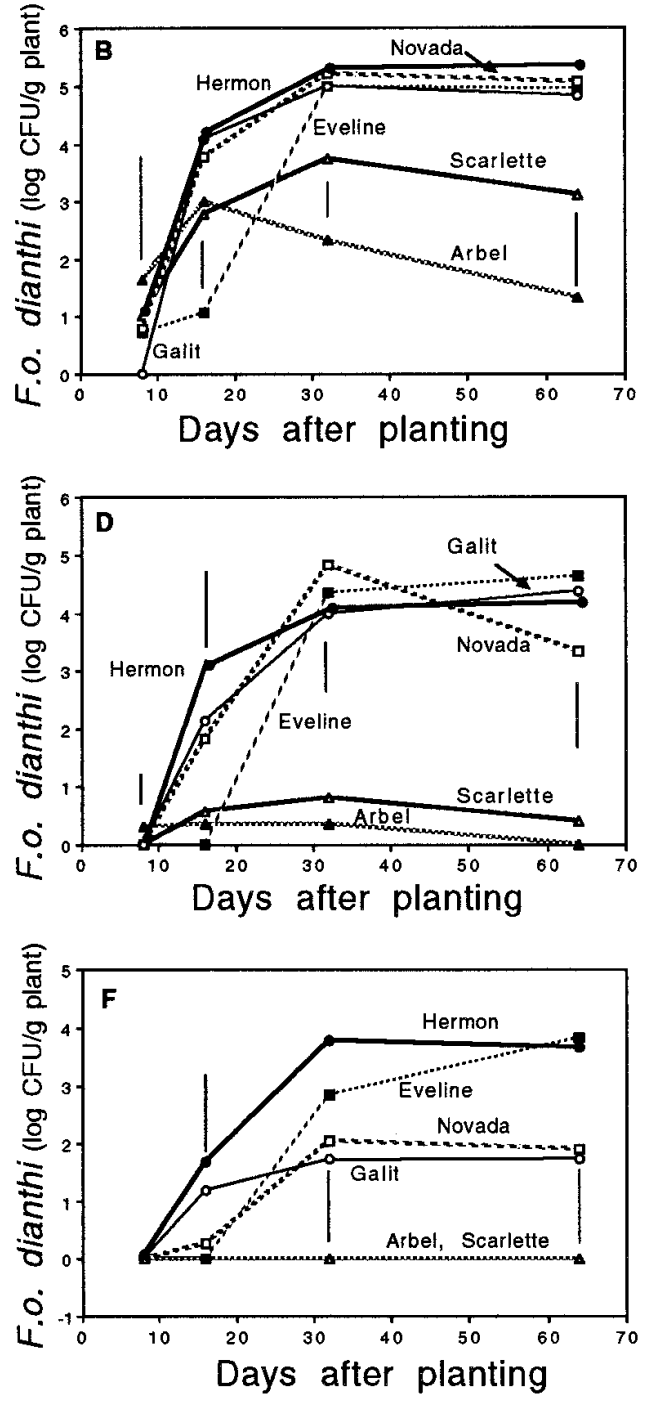

Fig. 3. Colonization frequency and the number of Fusarium oxysporum $\mathrm{f}$. sp. dianthi colony forming units (CFU) recovered from three parts of carnations stems of five carnation cultivars artificially inoculated with the pathogen and planted in a net-house in July 1995. (A and B) basal part of stem (0 to $2 \mathrm{~cm}$ above ground level); (C and D) middle part (5 to $7 \mathrm{~cm}$ above ground level); (E and F) upper part (10 to $12 \mathrm{~cm}$ above ground level). Colonization was evaluated 64 days after planting. Bars followed by common letters do not differ significantly as indicated by LSD tests (at $P \leq 0.05$ ). Vertical lines represent the LSD for each sampling date. Cultivars: Her. = Hermon, Ga. = Galit, Nov. = Novada, Eve. $=$ Eveline, Ar. $=$ Arbel, and Sca. $=$ Scarlette 
cular diseases such as Verticillium dahliae or formae speciales of Fusarium $(3,9,16,18)$ is not affected by the conditions of the test; resistant cultivars remain symptomless even when conditions are conducive to the pathogen. In all experiments conducted in this study, whether conducted in the field or under artificial inoculations, Arbel and Scarlette remained symptomless.

Nonexpression of disease symptoms does not necessarily indicate that the pathogen has failed to infect the host. $F$. oxysporum $\mathrm{f}$. sp. dianthi had colonized and was reisolated from the basal stem parts of all cultivars, including Arbel and Scarlette. Isolation of a wilt pathogen from the basal stem parts of resistant plants in artificially inoculated plants is not uncommon. Baayen and De Maat (5) reported that microconidia of $F$. oxysporum f. sp. dianthi were carried passively 5 to $10 \mathrm{~cm}$ into stems of a resistant carnation cultivar within $24 \mathrm{~h}$ after immersing cut ends of the roots in a conidial suspension or after pouring a suspension on the soil. They concluded that passive spore transport is an inoculation artifact that should be taken into account when interpreting experimental results. However, experiments presented in this study demonstrated that the pathogen had also colonized, and was recovered from, basal stem parts of plants grown in the field (Fig. 3). Nevertheless, this did not lead to the development of disease in Arbel or Scarlette. This emphasizes the difference between resistance to penetration of the pathogen and resistance to the disease (27). Based on the data, it appears that Arbel and Scarlette exhibit a novel type of resistance to Fusarium wilt induced by $F$. oxysporum f. sp. dianthi race 2 .

The inheritance of resistance to $F$. $o x$ ysporum f. sp. dianthi is not fully understood, and it may vary among the different races of the pathogen. Whereas Demmink et al. (17) suggested that resistance to race 1 is monogenic and dominant, Baayen et al. (7) concluded that resistance to race 1 was not necessarily monogenic and dominant but could be governed by one or several genes. Regarding resistance to race 2, a number of studies have shown that the inheritance of resistance to $F$. oxysporum $\mathrm{f}$. sp. dianthi race 2 is partial and polygenic and relies on a complex system of host reactions $(4,15,25,28)$. The genetic basis for resistance in Arbel and Scarlette has yet to be studied thoroughly. However, preliminary results involving progenies from a self cross of Scarlette suggest that there may be a single major gene that is segregating. Approximately 25\% of the offspring from these crosses lost their complete resistance when grown under conditions highly conducive to the pathogen (G. Scovel and Y. Ben-Yephet, unpublished).
Finding complete resistance in carnation to Fusarium wilt may have considerable implications in disease management. Race 2 of the pathogen is the most prevalent worldwide $(2,20)$ and the predominant population of $F$. oxysporum f. sp. dianthi in Israel $(10,23)$. Since all cultivars that are currently used commercially exhibit a partial type of resistance to race 2, growers in Israel routinely fumigate the soil (with methyl-bromide) prior to planting. Nevertheless, Fusarium wilt develops occasionally despite this treatment and causes substantial yield losses. Planting cultivars such as Arbel and Scarlette, which exhibit complete resistance to Fusarium wilt, may reduce soil fumigation.

\section{ACKNOWLEDGMENTS}

Contribution from the Agricultural Research Organization, The Volcani Center, Bet Dagan 50250, Israel. No 1956-E, 1996 series. We thank W. E. Fry for helpful comments; M. Lampel, Y. Szmulewich, and A. Zveibil for assistance in the field and artificial inoculation tests; and the nursery of Breir and Son (Bene Ziyyon) and Seeman's Nursery (Bet Yizhaq) for supplying cuttings of carnation cultivars Arbel and Scarlette.

\section{LITERATURE CITED}

1. Agrios, G. N. 1988. Plant Pathology. Academic Press, San Diego, CA.

2. Aloi, C., and Baayen, R. P. 1993. Examination of the relationships between vegetative compatibility groups and races on Fusarium oxysporum f. sp. dianthi. Plant Pathol. 42:839-850.

3. Alon, H., Katan, J., and Kedar, N. 1974. Factors affecting penetrance of resistance to Fusarium oxysporum f. sp. lycopersici in tomatoes. Phytopathology 64:445-451.

4. Arus, P., Llaurado, M., and Pera, J. 1992. Progeny analysis of crosses between genotypes resistant and susceptible to Fusarium oxysporum f. sp. dianthi race 2. Acta Hortic. 307:57-65.

5. Baayen, R. P., and De Maat, A. L. 1987. Passive transport of microconidia of Fusarium oxysporum f. sp. dianthi in carnation after root inoculation. Neth. J. Plant Pathol. 93:3-13.

6. Baayen, R. P., and Elgersma, D. M. 1985. Colonization and histopathology of susceptible and resistant carnation cultivars infected with Fusarium oxysporum f. sp. dianthi. Neth. J. Plant Pathol. 91:119-135.

7. Baayen, R. P., Sparnaaij, L. D., Jansen, J., and Niemann, G. J. 1991. Inheritance of resistance in carnation against Fusarium oxysporum $\mathrm{f}$. sp. dianthi races 1 and 2, in relation to resistance components. Neth. J. Plant Pathol. 97:73-86.

8. Ben-Yephet, Y., Melero, J. M., and DeVay, D. E. 1988. Interaction of soil solarization and metham-sodium in the destruction of Verticillium dahliae and Fusarium oxysporum f. sp. vasinfectum. Crop Prot. 7:327-331.

9. Ben-Yephet, Y., and Pilowsky, M. 1979. A method for determining susceptibility of tomatoes to Verticillium dahliae in greenhouse. Plant Dis. Rep. 63:66-69.

10. Ben-Yephet, Y., Reuven, M., Lampel, M., Nitzani, Y., and Mor, Y. 1992. Fusarium oxysporum $\mathrm{f}$. sp. dianthi races in carnation. (Abstr.) Phytoparasitica 20:225.

11. Ben-Yephet, Y., Reuven, M., and Mor, Y.
1993. Selection methods for determining resistance of carnation cultivars to Fusarium oxysporum f. sp. dianthi. Plant Pathol. 42:517-521.

12. Ben-Yephet, Y., Reuven, M., Zviebil, A., and Shtienberg, D. 1996. Effect of abiotic variables on the response of carnation cultivars to Fusarium oxysporum f. sp. dianthi. Plant Pathol. 45:98-105.

13. Ben-Yephet, Y., and Shtienberg, D. 1994 Effect of solar radiation and temperature on Fusarium wilt in carnation. Phytopathology 84:1416-1421.

14. Ben-Yephet, Y., Shtienberg, D., Reuven, M., and Mor, Y. 1993. Response of carnation cultivars to Fusarium oxysporum f. sp. dianthi in the field. Neth. J. Plant Pathol. 99:3-12.

15. Blanc, H. 1983. Carnation breeding for resistance to Fusarium oxysporum f. sp. dianthi. Practical achievement of resistant cultivars. Acta Hortic. 141:43-47.

16. Cirulli, M., and Ciccarese, F. 1980. Influenza di alcuni fattori sull espressione delle resistenze poligenica e monogenica a Fusarium oxysporum f. sp. lycopersici nel pomodoro. Inform. Fitopatol. 11-12:49-53.

17. Demmink, J. F., Baayen, R. P., and Sparnaaij, L. D. 1989. Evaluation of the virulence of races 1,2 and 4 of Fusarium oxysporum f. sp. dianthi in carnation. Euphytica 42:55-63.

18. Elgersma, D. M., MacHardy, W. E., and Beckman, C. H. 1972. Growth and distribution of Fusarium oxysporum f. sp. lycopersici in near-isogenic lines of tomato resistant or susceptible to wilt. Phytopathology 62:12321237.

19. Fry, W. E. 1982. Principles of Plant Disease Management. Academic Press, New York.

20. Garibaldi, A. 1983. Resistenza di cultivar di garofano neiconfornti di otto patoptipi di Fusarium oxysporum f. sp. dianthi (Prill. et Del.) Snyd. et Hans. Riv. Ortoflor. Ital. 67:261-270.

21. Harling, R., Taylor, G. S., Matthews, P., and Arthur, A. E. 1988. The effect of temperature on symptom expression and colonization in resistant and susceptible carnation cultivars infected with Fusarium oxysporum f. sp. dianthi. J. Phytopathol. 121:103-117.

22. Jones, J. P., Crill, P., and Volin, R. B. 1975. Effect of light duration on Verticillium wilt of tomato. Phytopathology 65:647-648.

23. Manulis, S., Kogan, N., Reuven, M., and BenYephet, Y. 1994. The use of the RAPD technique for the identification of Fusarium oxysporum f. sp. dianthi from carnation. Phytopathology 84:98-101.

24. Nash, S., and Snyder, W. C. 1962. Quantitative estimations of propagules of the bean root rot Fusarium in field soils by plate counts. Phytopathology 52:567-572.

25. Niemann, G. J. 1992. The mechanism of resistance of carnation to wilt diseases. Acta Hortic. 307:29-37.

26. Parlevliet, J. E. 1986. Identification and evaluation of quantitative resistance. Pages 215-284 in: Plant Disease Epidemiology. Genetics, Resistance and Management. K. J. Leonard and W. E. Fry, eds. McGraw-Hill, New York.

27. Robinson, R. A. 1976. Plant Pathosystems. Springer-Verlag, Berlin. 184 pp

28. Sparnaaij, L. D., and Demmink, J. F. 1977. Progress towards Fusarium resistance in carnation. Acta Hortic. 71:107-113.

29. Tramier, R., Anthoni, A., Bettachini, A., and Metay, C. 1983. Studies of Fusarium wilt resistance in carnation. Acta Hortic. 141:4954. 